\title{
Unpacking the African backlash to the International Criminal Court (ICC): The case of Uganda and Kenya
}

\author{
foe Oloka-Onyango*
}

\begin{abstract}
From early bright beginnings and close cooperation, African relations with the International Criminal Court (ICC or Court) bave recently witnessed a sharp deterioration. The explanations for this fall-out vary from the personal style of the first Prosecutor of the Court-Luis Moreno Ocampo-to the lack of a comprehensive appreciation of the reasons for which the institution was established in the first instance. This article specifically zeroes in on the troubled interactions between the Court and the governments of Uganda and Kenya. These two instances demonstrate that while the charge of antiAfrican bias has become the dominant discourse of contemporary scholarship on the issue, structural and systemic factors are not given enough attention. Particular attention is given to the way the cases of the Lord's Resistance Army (LRA) and President Uburu Kenyatta (from Uganda and Kenya respectively) found their way to the ICC and the subsequent developments relating thereto. In doing so, the article explores, among other factors, the way International Criminal Justice was politicised, and its links to enduring questions of global political and economic inequality. Such conditions of inequality find manifestation in the backlash by African countries towards what has been described as the ICC's selective approach. At the same time, opportunism and double-standards abound on all sides as there is both an inconsistent and hypocritical embrace of the basic tenets of International Criminal Law and Justice. Ultimately, the victims of human rights violations are short-changed while those actors who really need to be brought to account remain beyond sanction.
\end{abstract}

* The author is a Professor of Law, Makerere University. 


\section{Introduction}

In many different respects, the relationship between African countries and the International Criminal Court (ICC or Court) could be equated to a marriage turned sour, ${ }^{1}$ with Kenya and Uganda at the centre of this marital discord. Courtship and marriage have been followed by honeymoon and what can only be described as irreconcilable differences. And as is the case with most marital disputes, both sides share a portion of the blame. Against the backdrop of a great deal of academic and political concern about the relationship between Africa and the ICC, this article sets out to provide a critical analysis of key occurrences. How is it that an institution which started off being viewed with a degree of acceptance and even favour, has ended up being so vilified? What implications does this have for the broader goal of fighting impunity? Lastly, how has the relationship between Africa and the ICC impacted on International Criminal Law and its institutional growth?

Such an inquiry is especially important given the transition in the office of the Prosecutor from its first occupant, the Argentine Luis Moreno Ocampo to Gambian Fatou Bensouda, herself an African and from whom a different kind of relationship with the continent was expected. In other words, although initial commentary on the issue pointed in the main to relational and episodic factors-with Ocampo derided for his aggressive and flamboyant approach to the issues-quite obviously there are structural and systemic factors which are more determinative and require further reflection.

This article begins with some background to the general relationship between Africa and the ICC by first of all reviewing the 'situations' which have found their way to the Court and the manner in which they have done so. The analysis moves on to a detailed consideration of the politics surrounding the referral of Joseph Kony and the high command of the Lord's Resistance Army (LRA) in Uganda and the referral and aborted trial of Kenyan President Uhuru Muigai Kenyatta. The final section of the article provides a more schematic rendering of the tensions which that affected the relationship between each country and the ICC, exploring in the process the intricacies of what has come to be known as the ICC's 'Africa problem'.

Cole R, 'Africa's relationship with the International Criminal Court: More political than legal' 14(2) Melbourne International Law Journal, 2014. 


\section{The backdrop: courtship and honeymoon}

Although a great deal of effort and enthusiasm accompanied the discussion and eventual adoption of the Rome Statute of the International Criminal Court (Rome Statute) in 1998, for several months after it came into existence in July 2002, not much was initially heard from the institution. Then in December, 2003, a referral of the Kony case was made. At a highly-publicised press conference in London a month later, Prosecutor Ocampo and Ugandan President Yoweri Kaguta Museveni met to endorse the referrals, presenting what Victor Peskin described as '.. a lasting image of the ICC's dependence on state power and its need to cultivate state support'. ${ }^{2}$ Since the referrals and issuance of arrest warrants against Kony, the trajectory of cases at the ICC over the next several years involved only those from the African continent, as is evident from the data in the table below:

Table 1 - Summary of African situations at the ICC $^{3}$

\begin{tabular}{|c|c|c|c|}
\hline Situation & Indictee(s) & Initiator & Status \\
\hline 1. Uganda & $\begin{array}{l}\text { Joseph Kony } \\
\text { Okot Odhiambo } \\
\text { Dominic Ongwen } \\
\text { Vincent Otti Lagony } \\
\text { Raska Lukwiya }\end{array}$ & $\begin{array}{l}\text { Government } \\
\text { of Uganda }\end{array}$ & $\begin{array}{l}\text { At large } \\
\text { Deceased } \\
\text { On trial } \\
\text { Deceased } \\
\text { Deceased }\end{array}$ \\
\hline $\begin{array}{l}\text { 2. Central } \\
\text { African } \\
\text { Republic } \\
\text { (CAR) }\end{array}$ & $\begin{array}{l}\text { Kilolo Musamba } \\
\text { Fidéle Babala Wandu } \\
\text { Jean-Jacques Mangenda } \\
\text { Kabongo } \\
\text { Narcisse Arido } \\
\text { Jean-Pierre Bemba Gombo }\end{array}$ & $\begin{array}{l}\text { Government } \\
\text { of CAR }\end{array}$ & $\begin{array}{l}\text { Pre-trial (released) } \\
\text { Pre-trial (released) } \\
\text { Pre-trial (released) } \\
\text { Pre-trial (released) } \\
\text { On trial }\end{array}$ \\
\hline $\begin{array}{l}\text { 3. Cotê } \\
\text { d'Ivoire }\end{array}$ & $\begin{array}{l}\text { Laurent Gbagbo } \\
\text { Charles Blé } \\
\text { Simone Gbagbo }\end{array}$ & $\begin{array}{l}\text { ICC Prosecu- } \\
\text { tor }\end{array}$ & $\begin{array}{l}\text { Pre-trial } \\
\text { Pre-trial } \\
\text { Not in Court }\end{array}$ \\
\hline
\end{tabular}

2 Peskin V, 'Caution and confrontation in the International Criminal Court's pursuit of accountability in Uganda and Sudan' 31(3) Human Rights Quarterly, 2009, 656.

3 As at 25 April 2017. 


\begin{tabular}{|c|c|c|c|}
\hline Situation & Indictee(s) & Initiator & Status \\
\hline $\begin{array}{l}\text { 4. Demo- } \\
\text { cratic Re- } \\
\text { public of } \\
\text { Congo } \\
\text { (DRC) }\end{array}$ & $\begin{array}{l}\text { Bosco Ntaganda } \\
\text { Germain Katanga } \\
\text { Thomas Lubanga Dyilo } \\
\text { Mathieu Ngudjolo Chui } \\
\text { Calixte Mbarushimana } \\
\text { Sylvestre Mudacumura }\end{array}$ & $\begin{array}{l}\text { Government } \\
\text { of DRC }\end{array}$ & $\begin{array}{l}\text { Pre-trial } \\
\text { Convicted } \\
\text { Convicted } \\
\text { Appeal } \\
\text { Acquitted } \\
\text { At large }\end{array}$ \\
\hline $\begin{array}{l}\text { 5. Sudan } \\
\text { (Darfur) }\end{array}$ & $\begin{array}{l}\text { Abdallah Banda } \\
\text { Omar al-Bashir } \\
\text { Ahmed Haroun } \\
\text { Abdel Rahim Hussein } \\
\text { Ali Kushayb } \\
\text { Bahr Abu Garda } \\
\text { Saleh Jerbo }\end{array}$ & $\begin{array}{l}\text { UN Security } \\
\text { Council }\end{array}$ & $\begin{array}{l}\text { Pre-trial } \\
\text { Not in Court } \\
\text { Not in Court } \\
\text { Not in Court } \\
\text { Not in Court } \\
\text { Acquitted } \\
\text { Deceased }\end{array}$ \\
\hline 6. Libya & $\begin{array}{l}\text { Muammar el-Gaddafi } \\
\text { Saif al-Islam Gaddafi } \\
\text { Abdullah Senussi }\end{array}$ & $\begin{array}{l}\text { UN Security } \\
\text { Council }\end{array}$ & $\begin{array}{l}\text { Deceased } \\
\text { Not in Court } \\
\text { Not in Court }\end{array}$ \\
\hline 7. Kenya & $\begin{array}{l}\text { Mohammed Ali } \\
\text { Henry Kosgey } \\
\text { Francis Muthaura } \\
\text { Uhuru Muigai Kenyatta } \\
\text { William Ruto } \\
\text { Joshua arap Sang } \\
\text { Walter Osapiri Barasa }\end{array}$ & $\begin{array}{l}\text { ICC } \\
\text { Prosecutor }\end{array}$ & $\begin{array}{l}\text { Charges dropped } \\
\text { Charges dropped } \\
\text { Charges dropped } \\
\text { Charges dropped } \\
\text { Charges dropped } \\
\text { Charges dropped } \\
\text { Not in Court }\end{array}$ \\
\hline 8. Mali & $\begin{array}{l}\text { Ahmad Al Mahdi Al Faqi, } \\
\text { (a.k.a Abu Tourab) }\end{array}$ & $\begin{array}{l}\text { Government } \\
\text { of Mali }\end{array}$ & Pre-trial \\
\hline
\end{tabular}

Source: Website of the International Criminal Court (Situations under Investigation)-<http://www.icc-cpi. int/en_menus/icc/situations $\% 20$ and $\% 20$ cases/situations/Pages/situations $\% 20$ index.aspx $>$ last accessed 18 March 2020.

The table above demonstrates that although all the African references are rooted in the black letter of the law, each reflects different imperatives and rationales for invoking the legal power and jurisdiction of the ICC. In part, this is reflected by the three distinct categories into which they can be grouped, viz, State referrals, cases sent by the Security Council and Prosecutor-initiated investigations.

Aside from the purely legal, the table depicts a number of salient facts about the relationship between Africa and the ICC, aside from the most obvious 
that all situations under review emanated from the continent. The first situation (Uganda) and that of three others (CAR, the DRC and Mali) were referred by the governments in each of these countries. Out of those four, three (Ugan$\mathrm{da} 4, \mathrm{CAR}$ and DRC5) were referred with the active encouragement of the ICC Prosecutor. Indeed, despite appearances to the contrary, the initial step on the way to referral was begun in The Hague and not in the capitals of the referring countries. All four involved anti-government insurgents or 'rebels' implicated in serious and sustained atrocities and were initially muted about the culpability of the referring government.

Two of the situations (Darfur and Libya) were referred by the Security Council, implicating serving heads-of-state (Bashir of Sudan and Gaddafi of Libya) while two were initiated by the ICC prosecutor proprio motu (Cote d'Ivoire and Kenya), concerning post-election violence. It should also be pointed out that as at the end of April 2017, only one other country — the case of Georgia—was the focus of investigation at the ICC. The above imperatives and their implications will be further explored following a review of the specific cases of Uganda and Kenya.

\section{Joseph Kony, the 'national interest' and the ICC}

As the first country in the world with which the ICC had intimate dealings, Uganda epitomizes the history of love and hate between Africa and the ICC, or in the words of Nouwen, a marriage of convenience. ${ }^{6}$ The initial reference of the Northern Uganda situation by President Museveni to the ICC in December 2003 was done over strenuous objections from domestic civil society and the local human rights community. ${ }^{7}$ In this respect, the referral represented a reversion on the initial design of the ICC in which it was believed that states would be

4 Wegner P, 'Self-referrals and lack of transparency at the ICC - The Case of northern Uganda' Justice in Conflict, 4 October 2011 -<https://justiceinconflict.org/2011/10/04/self-referrals-and-lack-oftransparency-at-the-icc- $\% \mathrm{E} 2 \% 80 \% 93$-the-case-of-northern-uganda/.> on 11 February 2020.

5 Stigen J, The relationship between the International Criminal Court and national jurisdictions: The principle of complementarity, Martinus Nijhoff Publishers, Leiden, 2008.

6 Nouwen S and Werner W, 'Doing justice to the political: The International Criminal Court in Uganda and Sudan' 21(4) European Journal of International Law, 2011, 941-965.

Okello C, 'The false polarisation of peace and justice in Uganda' Expert Paper for Workshop 2Justice in Situations of Ongoing Conflict, International Center for Transitional Justice, Nuremberg, June 2007. See also Waddell N and Phil C, Courting conflict? Justice, peace and the ICC in Africa, Royal African Society, London, 2008. 
reluctant to have their nationals investigated by such an international body, the argument being that the main culprits to be targeted by such a court would be state actors themselves. ${ }^{8}$ Of course, where the actors are not part of the state, and are in fact ranged in rebellion against it, a state would have no difficulty in making a referral, and would even welcome it. As a matter of fact, the referral was used by the Ugandan Government to achieve a clearly political goal. ${ }^{9}$

But President Museveni's actions were not simply to internationalise the conflict in northern Uganda. They were also designed to buttress his credentials as the regional power broker, and to divert attention from a costly misadventure in the DRC. ${ }^{10}$ It is not by coincidence that the overtures to the ICC were taken in parallel to the judicial claim filed by the DRC at the International Court of Justice (ICJ) with the proceedings against Uganda being commenced in mid-2003 while a judgment was eventually returned against the country at the end of 2005 . Meanwhile, arrest warrants were issued on 8 July 2005 and 27 September 2005 for Joseph Kony and four members of the LRA high command on 33 separate counts of war crimes and crimes against humanity, including murder, rape, enlisting of children, and sexual enslavement.

When peace talks were initiated between the Government and the LRA in mid-2006, ${ }^{11}$ the ICC insisted on pursuing the referrals irrespective of the Juba peace negotiations taking place between the two sides. This angered the Ugandan President and led to the first souring in the relationship. ${ }^{12}$ Although the ICC made a pretense of supporting the measures taken by Uganda with regard to the traditional justice rites of Mato Oput and its ilk, it was a lukewarm embrace. ${ }^{13}$ In a way however, the ICC process did undermine efforts at a victim-oriented resolution of the conflict by focusing attention on capture, prosecution and conviction of only the LRA. At an international conference in Nuremburg, the ICC Prosecutor was quoted as saying, 'calling for amnesties, the granting of immunities and other ways to avoid prosecutions.... are not consistent with the Rome Statute....

\footnotetext{
8 Arsanjani M and Reisman M, 'The law-in-action of the International Criminal Court' 99(2) American Journal of International Law, 2005, 385-403.

9 Nouwen $\mathrm{S}$ and Werner W, 'Doing justice to the political: The International Criminal Court in Uganda and Sudan', 949.

10 Green M, The wizard of the Nile: The bunt for Africa's most wanted, Portobello, London, 2008, 117-118.

11 Atkinson R, From Uganda to the Congo and beyond: Pursuing the Lord's Resistance Army, International Peace Institute, New York, 2009, 10.

12 Peskin V, 'Caution and confrontation in the International Criminal Court's pursuit of accountability in Uganda and Sudan', 658.

13 Allen $\mathrm{T}$, 'The International Criminal Court and the invention of traditional justice in northern Uganda' 107 Politique Africaine, 2007, 147-165.
} 
there can be no political compromise on legality and accountability'. ${ }^{14}$ Regardless of local developments, these remarks demonstrated that the ICC wanted to see the LRA prosecution through to its logical conclusion. Additionally, international organisations had a role to play in influencing the Prosecutor not to back down.

Matters were also not helped by the fact that the ICC approach was opposed by the local political leadership in Acholi land, Ugandan civil society at large, as well as by several academics and media pundits. ${ }^{15}$ Given the prominent manner in which the traditional justice elements featured in the peace settlement alongside the question of amnesty, the ICC felt that it was being blind-sided by the Ugandan Government. ${ }^{16}$ The referrals of the LRA obviously raised many questions about the role of the other party to the conflict, the Uganda Peoples' Defence Forces (UPDF). ${ }^{17}$

In an effort to underscore the importance the ICC ostensibly attached to its historical and ongoing links with Africa in general and to Uganda in particular, the $10^{\text {th }}$ anniversary of the adoption of the Rome Statute of the ICC was held in the Ugandan capital, Kampala in mid-2010.18 By that time however, interactions between the country and the institution were already heading downhill. ${ }^{19}$ What had seemed like a marriage made in heaven had quickly deteriorated into a relationship fast on its way to Hell. And then the Kenyan referrals were announced. Museveni must have felt they were too close to home for comfort. Hence, at the inauguration of President Kenyatta in early 2013, Museveni saluted the Kenyan voters for rejecting what he described as ICC 'blackmail', even claiming that 'the

14 Moreno-Ocampo L, 'Building a future on peace and justice', Nuremberg, 24- 25 June 2007-<https:/ / www.icc-cpi.int/NR/rdonlyres/4E466EDB-2B38-4BAF-AF5F-005461711149/143825/LMO_ nuremberg_20070625_English.pdf> on 18 March 2020.

15 Apuuli P, 'Peace over justice: The Acholi Religious Leaders Peace Initiative (ARLPI) vs The International Criminal Court (ICC) in Northern Uganda' 11(1) Studies in Ethnicity and Nationalism, 2011, 116-129. See also Apuuli P and Allen T, 'The International Criminal Court and the invention of traditional justice in Northern Uganda' 107 Politique Africaine,2011.

16 See Nouwen S and Werner W, 'Doing justice to the political: The International Criminal Court in Uganda and Sudan', 954. Arsanjani M and Reisman M, 'The law-in-action of the International Criminal Court', 394-395. Schabas W, Unimaginable atrocities: Justice, politics, and rights at the war crimes tribunals, Oxford University Press, Oxford, 2012, 196.

17 Odora O, 'Museveni and the International Criminal Court: An alternative view' 1 Zanzibar Yearbook of Law, 2011, 173.

18 Secretariat, Assembly of States Parties International Criminal Court, 'Review conference of the Rome Statute of the International Criminal Court', Official Records, Kampala, 31 May - 11 June 2010.

19 Sadat N, 'On the shores of Lake Victoria: Africa and the review conference for the International Criminal Court’ Legal Studies Research Paper Series, Paper No 10-06-04, Washington University in Saint Louis, School of Law, 16 June 2010. 
usual opinionated and arrogant actors' wanted to install leaders of their choice in Africa and '... eliminate the ones they do not like'. ${ }^{20}$

Still, the important question remains; why did the Ugandan situation produce such a bitter and enduring stand-off? The first reason lies in the highly opportunistic manner in which its case got to the ICC. ${ }^{21}$ For Museveni and the Uganda Government, the Kony referral was a convenient way of internationalising what had largely been a domestic problem. Making the referral would serve to conceal the Government's own wrongdoing in its policies of encampment and scorched-earth retaliation, which had led to the displacement and victimisation of millions in so-called 'protected' camps. ${ }^{22}$ On the other hand, the ICC viewed Joseph Kony (and the LRA) as a rebel without a cause, leading the Prosecutor to believe that he had an open-and-shut case that would most certainly result in conviction if pursued and thereby inaugurate the Court's functionality with success. This belief may in fact have influenced the Office of the Prosecutor to focus largely on the LRA's atrocities, and less on the Government's own culpability. ${ }^{23}$ The relationship was thus initially thought to be a win-win for both parties. It is therefore not surprising that such an illegitimately motivated alliance would sour soon after as events unfolded contrary to the parties' (especially Kampala's) expectations.

As investigations progressed and the implications of Government culpability could not simply be swept under the carpet, Museveni changed tact by emphasising peace over justice accompanied by a nod to the traditional mechanisms of dispute resolution in Northern Uganda. ${ }^{24}$ Such a shift would allow for the sleeping (Government) dogs of the northern war to lie low while the extra-legal military efforts were stepped up in the quest to find (and kill) Kony. ${ }^{25}$ Needing to

20 Vision reporter, 'Museveni's speech at Uhuru's inauguration' New Vision, 10 April $2013-<$ https:// www.newvision.co.ug/new_vision/news/1317104/musevenis-speech-uhurus-inauguration $>$ on 11 February 2020.

21 Clarke K, Fictions of justice: The International Criminal Court and the challenge of legal pluralism in sub-Saharan Africa, Cambridge University Press, Cambridge, 2010, especially Chapter 3.

22 Branch A, Displacing buman rights: War and intervention in Northern Uganda, Oxford University Press, Oxford, 2001.

23 Atkinson R, 'From Uganda to the Congo and beyond: Pursuing the Lord's Resistance' International Peace Institute, 2009.

24 Letter dated 16 July 2007 from the Permanent Representative of Uganda to the United Nations addressed to the President of the Security Council, UNSC S/2007/435 (2007).

25 Gerson M, 'Joseph Kony and the international effort to bring him to justice' Washington Post, 26 January 2011 - < https://www.washingtonpost.com/opinions/joseph-kony-and-the-international-effort-to-bring-him-to-justice/2012/01/26/gIQAYk04TQ_story.html?utm_term=.115f79c7235c.> on 11 February 2020. 
demonstrate some minimal value for the money invested in the institution since 2002, and seeing his star case fly out the window, the ICC Prosecutor invoked Article 53 of the Rome Statute, which provides for a rejection of a request for the review of a situation. ${ }^{26}$

An element of duplicity on the part of the Ugandan Government with regard to the ICC becomes even more apparent when its reaction to Sudanese President Bashir's referral to the Court in 2009 is examined in depth against the history of accusations the same Ugandan Government levelled against him and his Government in the past, alleging that he/it was funding the LRA. As recently as 2014, Uganda had accused Sudan of resuming its support for the LRA rebels to the extent that Uganda filed a complaint with the Organisation of Islamic Cooperation (OIC). ${ }^{27}$ One would imagine that Uganda would not be quick in leaping to the defence of Bashir as against the ICC when in the past, it accused him of supporting/funding rebels in a case it 'voluntarily' referred to the same Court. That it would do so can only, ipso facto, point to double standards. It is plausible to thus assume that although Uganda joined the cacophony of African states expressing concern about the Sudan referrals, Kampala was not overly distressed about the lodestone placed on Bashir's neck.

In contrast to the situation of Sudan, the referral of Libya to the ICC was another matter because it involved President Gaddafi, a long-time ally of the regime in Uganda. Museveni then declared that he was 'totally allergic to foreign, political, and military involvement in sovereign countries, especially the African countries'. ${ }^{28}$ True to his (new) word, Museveni became one of the most vociferous opponents of the ICC within the African Union (AU) and instigated some of the discussions around not simply non-cooperation with the office of the Prosecutor, but complete withdrawal from the Rome Statute. ${ }^{29}$

26 Human Rights Watch Policy Paper, "The meaning of "the interests of justice" in Article 53 of the Rome Statute' Human Rights Watch, 1 June 2005 -<https://www.hrw.org/news/2005/06/01/ meaning-interests-justice-article-53-rome-statute> on 11 February 2020.

27 'Uganda Accuses Khartoum of Resuming Support for LRA' Sudan Tribune, 26 April 2014 -<http:// www.sudantribune.com/spip.php?article50779> on 11 February 2020.

28 Nolan R, 'Museveni: Qaddafi bad, foreign intervention worse' Foreign Policy, 25 March 2011 -<http:/ / foreignpolicyblogs.com/2011/03/25/ugandas-museveni-qaddafi-bad-interventionworse/> on 11 February 2020.

29 AFP, 'Museveni calls for mass pull-out of african states from International Criminal Court' Daily Nation, 12 December 2014 -<http://www.nation.co.ke/news/politics/African-states-quit-ICCMuseveni/1064-2554310-5qe012/index.html> on 11 February 2020. Also see Miriri D, 'Uganda's Museveni calls on African nations to quit ICC' Reuters, 12 December $2014-<$ http://www.reuters. $\mathrm{com} /$ article/us-africa-icc/ugandas-museveni-calls-on-african-nations-to-quit-the-icc-idUSKBN0JQ1DO20141212> on 11 February 2020. 
However, duplicity was not just confined to Kampala or The Hague. Behind the scenes, the United States saw an opportunity in the Kony referrals to pursue its global anti-terrorism agenda, and hence supported the actions of the Ugandan Government against the LRA up to its elusive search for Kony and his lieutenants in the jungles of the DRC and the CAR. ${ }^{30}$

The Government's mixed signals over its 'Kony problem' - to wit seeking the prosecution of the LRA rebels internationally (before the ICC) on the one hand, while also advocating for domestic prosecution (and traditional forms of justice or 'peaceful reconciliation') on the local scene-continued to be manifested in the creation of a War Crimes division of the High Court, and later by raising no objection to the Hague trial of Dominic Ongwen captured in the Central African Republic, especially at a time when President Museveni was increasingly critical ${ }^{31}$ of the ICC. ${ }^{32}$ It should be noted that Dominic Ongwen was one of the five LRA leaders against whom the ICC issued arrest warrants following Uganda's referral of the matter. ${ }^{33} \mathrm{He}$ was thus part and parcel of the core LRAKampala-ICC story ab initio. The inconsistency in the Government's position was thus stark and logically suggestive of duplicity.

At the end of the day, in his relations with the ICC, Museveni was both able to have his cake and to eat it, deftly selecting when, where, how and on what terms and issues he chose to cooperate with the institution and on those over which he did not. He was also adept at jumping on the victimisation band-wagon when circumstances suited him, pushing the AU to adopt increasingly more hostile positions towards the institution. ${ }^{34}$ Ultimately, the Ugandan victims of both

30 Green M, The wizard of the Nile: The hunt for Africa's most wanted, 90-91.

31 Okiror E, 'Should Uganda celebrate Dominic Ongwen's transfer and trial?' International Justice Tribune, 13 January 2015 -<https://www.justicetribune.com/blog/should-uganda-celebrate-dominicongwens-transfer-and-trial $>$ on 11 February 2020.

32 Okiror E, 'Should Uganda celebrate Dominic Ongwen's transfer and trial?' International Justice Tribune, 13 January 2015 -<https://www.justicetribune.com/blog/should-uganda-celebrate-dominicongwens-transfer-and-trial $>$ on 11 February 2020. See also Tumwesigye B, 'Sending Ongwen to ICC was uncalled for' Red Pepper, 15 January 2015, 11. Ojok J, 'South African professor protests Ongwen trial in the Hague' Red Pepper, 19 March 2015, 6.

33 The five were: Joseph Kony, Vincent Otti, Okot Odhiambo, Dominic Ongwen and Raska Lukwiya. See ICC Press Release, 'Warrant of arrest unsealed against five LRA commanders' 14 October 2005 -<https://www.icc-cpi.int/legalAidConsultations?name=warrant+of+arrest+unsealed + against $+f i$ ve+lra + commanders $>$ on 1 February 2020.

34 AFP, 'Museveni calls for mass pull-out of African states from International Criminal Court' Daily Nation, 12 December 2014 -<http://www.nation.co.ke/news/politics/African-states-quit-ICCMuseveni/1064-2554310-5qe012/index.html> on 11 February 2020. Also see Miriri D, 'Uganda's Museveni calls on African nations to quit ICC' Reuters, 12 December 2014 -<http://www.reuters. $\mathrm{com} / \mathrm{article} / \mathrm{us}$-africa-icc/ugandas-museveni-calls-on-african-nations-to-quit-the-icc-idUSKBN0JQ1DO20141212> on 11 February 2020. 
the LRA and the UPDF were short-changed in the process as efforts directed towards truth and reconciliation were given short shrift and wider questions of accountability thus ignored. In contradistinction to the noble 'justice-oriented' aims for which the Rome Statute and the Court under it were envisioned, Uganda and the ICC had resorted to an alliance without 'righteous foundation'. Little good could therefore come out of it.

\section{Kenya in the dock: "Don't be vague; Let's go to the Hague"}

On 8 October 2014, Kenya's President Kenyatta became the first sitting head of state to appear before an international criminal tribunal, ${ }^{35}$ in his personal rather than presidential capacity. ${ }^{36}$ Although this appearance was only for a scheduling conference, its significance and repercussions were immense. In a speech made to the Kenyan Parliament the day before he flew out to Holland, Kenyatta was particularly keen to underscore the point that he would not 'put the sovereignty of more than forty million Kenyans on trial, since their democratic will should not be subject to another jurisdiction'. ${ }^{37}$ The President went on to take what he described as the 'extraordinary and unprecedented step' of appointing his deputy, Ruto, as Acting President while underscoring the point that his appearance at the Court was in a personal capacity.

Delivered to an attentive Kenyan public, Kenyatta had many other audiences in mind, including his fellow presidents around the continent and their regional organisation, the $\mathrm{AU}$, as well as the wider international community. Lastly, President Kenyatta was speaking directly to the ICC, which he accused of making 'unfounded and unproven accusations', of having a weak case against him that was not properly investigated, and of pursuing an agenda that undermined African leadership and sovereignty. ${ }^{38}$ Citing British Prime Minister David Camer-

35 Escritt T, 'Kenya's Kenyatta becomes first president to appear at global court' Reuters, 8 October $2014<$ http://uk.reuters.com/article/uk-kenya-court/kenyas-kenyatta-becomes-first-president-toappear-at-global-court-idUKKCN0HX0L620141008> on 11 February 2020.

36 Bikundo E, 'The president's two bodies: Uhuru Kenyatta at the International Criminal Court' 3(1) Griffith Journal of Law \& Human Dignity, 2015.

37 Pflanz M, 'Uhuru Kenyatta's ICC prosecution close to collapse as lawyers demand acquittal' Telegraph, 8 October 2014 -<http://www.telegraph.co.uk/news/worldnews/africaandindianocean/kenya/11149256/Uhuru-Kenyattas-ICC-prosecution-close-to-collapse-as-lawyers-demand-acquittal. html> on 18 March 2020.

38 See for example Pflanz M,'Kenyan president to go to Hague Court', Telegraph, 6 October 2014 -<http://www.telegraph.co.uk/news/worldnews/africaandindianocean/kenya/11143939/Kenyanpresident-to-go-to-Hague-court.html> on 11 February 2020. 
on's threats to withdraw from the European Court of Human Rights, ${ }^{39}$ Kenyatta hinted at pursuing similar action to its logical conclusion via the AU. ${ }^{40}$ Kenyatta's speech succinctly captured the two-faced relationship between the Court and political authorities in Africa. With the situation of Kenya, the negative African response to the ICC reached its apogee. And yet, the case would never have reached The Hague but for the wave and waft of domestic Kenyan politics. How did it get there?

\section{From Nairobi with love}

In the aftermath of the election violence of December 2007, then-President Mwai Kibaki and his main rival and contender for the presidency, Raila Odinga, hammered out an agreement that would end the bloodshed and hopefully move the country ahead through the formation of the Government of National Unity (GNU). Further addressing the issue, the Commission of Inquiry into Post-Election Violence (CIPEV) chaired by Kenyan Justice Philip Waki revealed that it had created a 'secret envelope', to be submitted to the Panel of Eminent Persons who had supervised the talks between the two sides and which contained the names of people who were, 'alleged by various witnesses to have perpetrated violence at some level'. ${ }^{41}$ The CIPEV recommended a thorough investigation of the violence and eventual prosecution of people alleged to have masterminded the bloodshed. The names would be kept secret by the Panel pending the establishment of a hybrid (local/international) special tribunal, with the CIPEV promising to forward the envelope to the ICC if the tribunal was either subverted or simply not created. ${ }^{42}$

However, attempts to establish a local court met serious objection and eventually failure when presented to Parliament. ${ }^{43}$ The most famous (or notorious) statement expressing the dominant sentiment in the House was, "don't be

39 Watt $\mathrm{N}$ and Bowcott $\mathrm{O}$, 'Tories plan to withdraw UK from European convention on human rights' The Guardian, 3 October 2014 -<http://www.theguardian.com/politics/2014/oct/03/tories-planuk-withdrawal-european-convention-on-human-rights $>$ on 11 February 2020.

40 For the resultant effect of this 'threat'/promise, see AFP, 'African Union members back Kenyan plan to leave ICC’ The Guardian, 1 February 2016 -<https://www.theguardian.com/world/2016/ feb/01/african-union-kenyan-plan-leave-international-criminal-court> on 11 February 2020. Adenaur K, Kriegler and Waki reports summarised version, revised edition, 2009, 47 and 69.

Adenaur K, Kriegler and Waki reports summarised version, 70-71.

43 Wambui C, 'Don't be vague; Let's go to Hague': Kenya's tumultuous relationship with the ICC' The Hague Institute For Global Justice, 27 August 2014-<http:/ /www.thehagueinstituteforglobaljustice. org/latest-insights/latest-insights/commentary/dont-be-vague-lets-go-to-hague-kenyas-tumultuous-relationship-with-the-icc/> on 11 February 2020. 
vague; let's go to The Hague." ${ }^{44}$ Both Kenyatta and Ruto-Cabinet members of the Government that proposed the Bill-joined those who were against a local tribunal and originally supported reference of the case to The Hague. ${ }^{45}$ This was initially because they suspected their names to be within the CIPEV Report and believed an ICC prosecution, as opposed to appearing before a locally established tribunal, would take too long to materialise, thereby offering no interference with their political survival and ambitions. This however was not to be, as the ICC intervention picked up speed. It soon became the case for Kenyatta and Ruto that they had to fight the ICC and decry its pursuance of their cases as a victimisation of Kenyan sovereignty by the West. ${ }^{46}$ What term would best be apt to describe this twist if not 'duplicity'? ${ }^{47}$

Despite the duplicitous nature of the demand for a referral of the case, the fact is that the creation of a local tribunal in Kenya at the time was indeed not realistically on the table. Even if a local tribunal had been established, there is little doubt that such a body would not have been able to initiate trials against the major alleged culprits given their stature and power within Kenya. Local, high level interference with the ICC process itself, particularly through witness tampering and refusal to cooperate with the Prosecution, points to this. ${ }^{48}$ But at the time the debate was going on in early 2009, The Hague seemed like a distant place where nothing much really happened. After all, there was no 'live' case-taking place in the ICC at the time to which one could point. Reference of the issue to the ICC was also part of a larger gamble; the betting was that the Prosecutor would either not proceed with the case, would take very long to initiate and effect prosecution or that the case would simply not garner the support of the judges who reviewed

${ }^{44}$ Wambui C, 'Don't be vague; Let's go to Hague': Kenya's tumultuous relationship with the ICC' The Hague Institute For Global Justice, 27 August 2014-<http:/ /www.thehagueinstituteforglobaljustice. org/latest-insights/latest-insights/commentary/dont-be-vague-lets-go-to-hague-kenyas-tumultuous-relationship-with-the-icc/> on 11 February 2020.

45 Brown $\mathrm{S}$ and Sriram C, 'The big fish won't fry themselves: Criminal accountability for post-election violence in Kenya' 111(443) African Affairs, 2012, 244-260.

46 Makinda SM, 'Kenya, Uhuru Kenyatta and politicising the International Criminal Court' The Conversation, 30 May 2013-<http://theconversation.com/kenya-uhuru-kenyatta-and-politicising-theinternational-criminal-court-14583> on 11 February 2020.

47 See Odero J, 'Uhuruto took themselves to The Hague' Kenya Stockholm Blog, 12 September 2013 -<https://kenyastockholm.com/2013/09/12/uhuruto-took-themselves-to-the-hague/> on 11 February 2020.

48 See Open Society Initiative, 'Witness interference in cases before the International Criminal Court', Briefing Paper, November 2016. Also see Institute for War \& Peace Reporting (IWPR), 'Further threats to ICC's Kenya witnesses: International court moves to protect some of those who will testify against deputy president' IWPR, ACR Issue 359, 28 August $2013-<$ https://iwpr.net/globalvoices/further-threats-iccs-kenya-witnesses $>$ on 11 February 2020. 
it. Both proved wrong, leaving only two other options on the table; play by the legal rules of the game, which carried with it the serious threat of a conviction if the matter went to trial, or revert to the political, both domestically within Kenya and on the international scene. ${ }^{49}$

Given that Kenyatta and Ruto were also prominent actors on the Kenyan scene and eyed the high office of President with an election drawing close, they had two options: Fight the charges separately and fail both in The Hague and in the Kenyan election, or come together. Although the two had been on opposing sides of the conflict and both had been referred for their respective roles on each of those sides, they quickly came to the conclusion that unity was better than jail. ${ }^{50}$ In a nutshell, the ICC referrals provided the stimulus for political (or at a minimum, electoral) unity. ${ }^{51}$ When the United States precipitously jumped into the fray warning that 'choices have consequences', implying that it would be a bad idea to elect individuals facing a criminal trial, the Kenyatta and Ruto (UhuRuto) Jubilee alliance had victory more or less sealed. ${ }^{52}$

In contrast to the belief that being in office would hamstring the newlyelected duo, quite the reverse turned out to be the case. The Kenyatta Government deployed its diplomatic muscle to full effect to stop the cases from proceeding. ${ }^{53}$ At home, Parliament passed a motion expressly calling for a withdrawal from the Rome Statute, and took some steps towards repealing the legislation that had domesticated the Rome Statute. ${ }^{54}$ The fight was taken into the East African region, leading to a resolution that the East African Court of Justice

49 Dowden R, 'Kenya and the ICC: 'Don't be vague, go to The Hague,"(but send Bush and Blair too)' African Arguments, 11 April 2013 -<http://africanarguments.org/2013/11/04/kenya-and-the-iccdont-be-vague-go-to-the-hague-but-send-bush-and-blair-too-by-richard-dwoden/ > on 11 February 2020. Nichols L, 'Don't be vague, go to The Hague,' in Nichols L (ed), The International Criminal Court and the end of impunity in Kenya, Springer International Publishing, Cham, 2015, 133.

50 Kendall S, 'UhuRuto' and other leviathans: The International Criminal Court and the Kenyan political order' 7(3) African Journal of Legal Studies, 2014, 399-427.

51 Mamdani M, 'Kenya Election 2013: The ICC Election' Makerere Institute of Social Research (MISR), Working Paper No.15, March 2013, 11-13.

52 Joselow G, "US Official says Kenya's elections have 'consequences"' Voice of America, 7 February 2013- <https://www.voanews.com/africa/us-official-says-kenyas-elections-have-consequences> on 18 March 2020.

53 Kituku W, 'The state of constitutionalism in Kenya-2013' in Murangira T (ed), The Annual State of Constitutionalism in East Africa 2013, Fountain Publishers, Kampala, 54.

54 Kulish N, 'Kenyan lawmakers vote to leave International Court' New York Times, 5 September 2013 -<http://www.nytimes.com/2013/09/06/world/africa/kenyan-lawmakers-vote-to-leave-international-court.html?pagewanted $=$ all\&_r $=0>$ on 18 March 2020 . 
take over the ICC cases. ${ }^{55}$ Then the pro- Kenyatta forces fanned out around the continent, masterfully playing the 'Africa-as-victim' card to full effect, eventually resulting in a resolution by the AU. The Kenyan diplomatic corps worked overtime to sell the cause of their bosses at the United Nations while African governments intensely lobbied the members of the Security Council to defer the cases. Aside from China and Russia, the votes marshaled were not enough to succeed in the matter. At the November, 2013, Conference of State Parties of the ICC, there was a failure to secure an amendment of the Rome Statute in line with the AU resolution, although some success was registered when the United Kingdom sponsored an amendment that would allow the Court to excuse 'high ranking officials from physical attendance at The Hague and allow them to appear via video link or other appropriate technology, ${ }^{56}$ Back in The Hague, the situation was not helped by what played out as a rather spectacular unraveling of the Kenyan cases. Out of the initial 'Ocampo-6' indictees, charges against three of them were dropped within a short span of time. ${ }^{57}$ In the pre-trial hearing of the Kenyatta case, although two of the judges agreed to send the case on to a full hearing, one judge's dissenting opinion was telling of the pitfalls ahead. ${ }^{58}$

Most observers were of the view that the Kenyatta case was a weak one, especially since the charges were on all fours with at least one of the acquitted three. ${ }^{59}$ The progressive reduction or disappearance of witnesses and the lack of cooperation on the part of the Kenyan Government compounded the situation. ${ }^{60}$ In this respect, the ICC appeared powerless both to compel the Govern-

55 See East African Legislative Assembly (EALA), Resolution of the Assembly seeking the EAC Council of Ministers to implore the International Criminal Court to transfer the case of the accused four Kenyans facing trial in respect of the aftermath of the 2007 Kenya general elections to the East African Court of Justice and to reinforce the treaty provisions, 26 April 2012 - <http://www.eala.org/uploads/Resolution \%20-\%20Hon $\% 20 \% 20$ Ogalos\%20document\%20-\%20Kenya\%20Elections\%20_2_.pdf> on 18 March 2020.

56 Kituku W, 'The state of constitutionalism in Kenya-2013’, 53.

57 The Prosecutor gave three reasons for taking this action, vi\%, the death and intimidation of several witnesses; non-cooperation of the Government of Kenya with the Prosecutor's office, and the abandonment of a key witness who accepted having received bribes. Statement by ICC Prosecutor on the Notice to withdraw charges against Mr Muthaura on 11 March $2013-<$ http://www.icc-cpi. int/en_menus/icc/press\%20and\%20media/press\%20releases/Pages/OTP-statement-11-03-2013. aspx> on 18 March 2020.

58 Kaberia J, 'ICC Judge withdraws from Kenya's Hague cases' Capital FM News, 27 April 2013-<http:// publicinternationallawandpolicygroup.org/wp-content/uploads/2013/06/WCPW_050613_Master-2.html\#ky4> on 18 March 2020.

59 Pflanz M, 'Uhuru Kenyatta's ICC prosecution close to collapse as lawyers demand acquittal' Telegraph, 8 October 2014 -<http://www.telegraph.co.uk/news/worldnews/africaandindianocean/kenya/11149256/Uhuru-Kenyattas-ICC-prosecution-close-to-collapse-as-lawyers-demand-acquittal. html > on 18 March 2020

60 Kenyans for Peace with Truth \& Justice (KPTJ), All bark no bite? State cooperation and the International Criminal Court, December 2014. 
ment to cooperate in the manner that it wanted it to, but also to provide basic protection to the witnesses in the case. Furthermore, western governments who were initially hostile to Kenyatta and had treated him like a pariah, warmed up to the new President, and reduced the pressure initially brought to bear on the Government.

With the upsurge in the threat of Al-Shabaab represented most graphically by the Westgate Mall attack in September 2013, and Kenya's prominent role in seeking a settlement to the 'problem' of Somalia, many western powers were no longer shy about doing business with the country. ${ }^{61}$ To cap it all, Kenyatta played the game of a compliant and cooperative - if slightly irritated_accused person, appearing when summoned to do so even if vigorously protesting his innocence and the capacity of the Court to try him. ${ }^{62}$ Political and economic imperatives saw Kenyatta gradually accepted back into the fold.

Ultimately, the final gauntlet in the saga was thrown down by the Court, which rejected a request for further time in the conduct of investigations and directed the Prosecutor to either proceed with the trial within a week of the order, or drop the charges altogether. According to the Court, responding to a request by the Prosecutor for an indefinite postponement of the trial until the cooperation of the Kenyan Government had been secured would be contrary to the interest of justice under the circumstances. ${ }^{63}$ Caught between a rock and a hard place, two days later, Prosecutor Bensouda announced that she was dropping the charges against President Kenyatta. ${ }^{64}$

\section{The large(r) problems of international justice: Unpacking the backlash}

While the examples of Kenya and Uganda give some insight into the 'African problem' at the ICC, to complete the picture, other developments need to be

61 Holvoet M and Medlir M, The ICC and its deteriorating relationship with Africa in light of the Kenya cases: What should the EU position be?, Institute for European Studies, Policy Brief, Issue 2013/09, November 2013-< http://www.ies.be/files/2013-09\%20MM_MH_pdf.pdf> on 18 March 2020.

62 Pflanz M, 'Uhuru Kenyatta's ICC prosecution close to collapse as lawyers demand acquittal' Telegraph, 8 October 2014 -<http://www.telegraph.co.uk/news/worldnews/africaandindianocean/kenya/11149256/Uhuru-Kenyattas-ICC-prosecution-close-to-collapse-as-lawyers-demand-acquittal. html> on 18 March 2020.

63 The Prosecutor v Uhuru Muigai Kenyatta, [ICC-01/09-02/11], 3 December 2014.

${ }^{64}$ See the notice of withdrawal of the charges against Uhuru Muigai Kenyatta (The Prosecutor $\mathrm{v}$ Uhuru Muigai Kenyatta) by the Office of the Prosecutor, ICC-01/09-02/11-983, 5 December 2014 -<https://www.icc-cpi.int/Pages/record.aspx?docNo=ICC-01/09-02/11-983> on 18 March 2020. 
reviewed and unpacked. The issues of specific unpacking in the following section of this article include the complex and sometimes paradoxical relationship between law and politics; concepts of justice in an international context; issues of head of state immunity and ultimately the relationship between peace and justice. But first, it is necessary to consider the specific elements in the relationship between the AU and the ICC that have led to the problem in the first instance.

\section{The $A U$ and the ICC}

The causes of the fall-out between the AU and the ICC have been described in numerous ways: as the result of an 'image problem', ${ }^{5}$ the lack of a communications strategy, ${ }^{66}$ the absence of a 'robust dialogue' between the Court and the $\mathrm{AU},{ }^{67}$ or the need for the appointment of a senior advisor on politics. ${ }^{68}$ Others have even asserted that the targeting is by Africa against the ICC, and not the reverse. ${ }^{69}$

While a great deal of commentary has reflected on the more immediate causes of the deterioration in the relationship, ${ }^{70}$ few have situated the tensions within the wider framework of the very nature and character of International Law and of the much larger issues affecting its development in the early $21^{\text {st }}$ century. It is the main argument of this article that the matter extends well beyond relational and episodic factors. There are structural and systemic issues in this matter which are more determinative and require further reflection. But what

65 Lamony S, 'Is the International Criminal Court really picking on Africa?' African Arguments, 18 April 2013 -<http://africanarguments.org/2013/04/16/is-the-international-criminal-court-reallypicking-on-africa-by-stephen-a-lamony/> on 18 March 2020.

66 Cacciatori M, 'The International Criminal Court must fix its anti-African image' The Conversation, 20 October $2014-<$ https://theconversation.com/the-international-criminal-court-must-fix-its-anti-african-image-32983> on 18 March 2020.

67 Mbaku J, 'Africa’s case against the ICC’ Brookings Institution, 13 March 2014 -<http:/ / www.brookings.edu/blogs/africa-in-focus/posts/2014/03/13-international-criminal-court-mbaku> on 18 March 2020.

68 Murithi T, 'Between political justice and judicial politics: Charting a way forward for the African Union and the International Criminal Court' in Werle G, Fernandez L and Vormbaum M (eds), Africa and the International Criminal Court, TMC Asser Press, The Hague, 2014.

69 Lyal S, 'Has ICC unfairly targeted Africa or has Africa unfairly targeted the ICC?' in Mariniello T (ed), The International Criminal Court in search of its purpose and identity, Routledge, London/New York, 2015.

70 Keppler, for example, argued that the response of the AU to the Bashir warrants did not represent the predominant view or approach of government officials or of civil society on the continent. The article made two mistakes, first collapsing government functionaries and civil society activists together, and second to claim that the criticisms were directed at the Security Council and not the Court. See Keppler E, 'Managing setbacks for the International Criminal Court in Africa' 56(1) Journal of African Law, 2012. 
is the main source of grievance of African leaders? The exclusive focus of the Court on situations only from the continent tops the list, even if this claim is tinged with blatant and opportunistic hypocrisy. ${ }^{71}$ According to this argument there are several other places—among them Honduras and North Korea ${ }^{72}$ which would be obvious situations for investigation, but Iraq, Israel, Palestine (especially Gaza), Sri Lanka, Syria, and Uzbekistan could also make suitable candidates. In the words of one African foreign minister, "there is not a single case at the ICC that does not deserve to be there. But there are many cases that belong there, that aren' $t$ ". ${ }^{73}$ Although the ICC announced several investigations in some of these and other countries including Columbia, Georgia, and most recently Ukraine, it is rather surprising that in over 10 years of existence, the remit of the Court had not extended beyond the continent.

Whatever opportunistic impulses may have driven the response of African presidents and the AU to the ICC, they represented a paradigm shift in International Law that requires deeper study and appreciation. Not since the 'Asian values' debate of the 1980s and 1990s have the doctrinal foundations of International Human Rights Law come under such serious challenge. ${ }^{74}$ The consequences of the current debate however, are much more far-reaching. ${ }^{75}$ As Nouwen and Werner point out, the original seed of the ICC/Africa relationship was conceived in a political fashion. It is thus very difficult for the ICC to mark distance from this DNA. ${ }^{76}$ Nevertheless, in responding to charges of an antiAfrican bias, the President of the Assembly of State's Parties to the Rome Statute of the ICC stated as follows:

71 Roth K, 'Africa Attacks the International Criminal Court' The New York Review of Books, 6 February 2014-< https://www.nybooks.com/articles/2014/02/06/africa-attacks-international-criminalcourt/> on 18 March 2020.

72 In 2014, an effort was commenced to have the Security Council refer North Korea to the ICC see Sengupta S, 'Coalition seeks to send North Korea to international court over rights abuses' New York Times, 25 October 2014 -<http://www.nytimes.com/2014/10/26/world/coalition-seeks-tosend-north-korea-to-international-court-over-rights-abuses.html?mabReward=RI\%3A12\&module $=$ WelcomeBackModal\&contentCollection=N.Y. $\% 20 \% 2 \mathrm{~F} \% 20$ Region\&region=FixedCenter\&actio $\mathrm{n}=$ click\&src $=$ recg\&pgtype $=$ article\&_r $=0>$ on 18 March 2020.

73 Sadat LN, 'On the shores of Lake Victoria: Africa and the Review Conference for the International Criminal Court', Legal Studies Research Paper Series, Paper No 10-06-04, 16 June 2010, 15-< https://papers.ssrn.com/sol3/papers.cfm?abstract_id=1626323> on 18 March 2020.

74 Amartya S, 'Human rights and Asian values: What Lee Kuan Yew and Le Peng Don't Understand about Asia' 217(2-3) The New Republic, 1997, 1-9.

75 Mukundi G, Africa and the ICC, Centre for the Study of Violence and Reconciliation, 6 March 2012.

76 Nouwen S \& Werner W, 'Doing justice to the political: The International Criminal Court in Uganda and Sudan'. 
Africa was a key player in the creation of the ICC. African states actively participated in the preparatory negotiations that led to the establishment of the Court, and ensured the reflection of many core African positions in the Statute, such as the principle of complementarity, the independence of the Prosecutor and judicial independence from the United Nations Security Council. But Africa's commitment to the Court did not stop with its establishment on paper. The first country to ratify the Statute, Senegal, came from Africa and today with 34 members Africa constitutes the largest regional grouping among states parties. It was probably because of the hope of the deterrent effect that many African states joined the Statute early on. ${ }^{77}$

The response of the Court to Africa seeks to capture and capitalise on the historical involvement of the continent both in its establishment and in its continuing growth and development. The other arguments for the Afro-focus of the ICC were the following: (i) the majority of cases had been referred by African governments themselves; (ii) a good number of these situations, such as Uganda, DRC and the Central African Republic involved a magnitude and gravity of violations that simply could not be ignored; (iii) the victims of the crimes were African and fully deserving of justice; (iv) the ICC is an international court, with not only the Prosecutor but several judges coming from Africa; (vi) the two cases where the Prosecutor's office deployed its proprio motu powers - Cote d'Ivoire and Kenya-were fully warranted by the circumstances; (v) some of the cases which were referred to for comparison were not states parties to the Rome Statute, and finally, (vi) the Security Council—which has three African members-made references in those instances which they felt warranted an ICC intervention. ${ }^{78}$

Taking each of these arguments separately, while it is true that the majority of cases were referred by African governments, the cases which have caused most problems were those involving sitting heads of state in which the referrals have come from elsewhere. The Bashir situation, for instance, provoked the AU into proposing an amendment to the text of the Rome Statute to provide direction to the Prosecutor on how to choose cases. ${ }^{79}$ The AU also passed a resolution

77 Statement by Tina Intellmann- President, Assembly of State Parties (ASP) to the International Criminal Court (ICC) at the Africa Legal Aid Conference on 'Africa and the International Criminal Court: Lessons learned and synergies ahead', Johannesburg, 9-10 September 2014.

78 Stearns S, 'African Union Says ICC Prosecutions Are Discriminatory' Voice of America, 4 July 2011 - <https://www.voanews.com/africa/african-union-says-icc-prosecutions-are-discriminatory $>$ on 18 March 2020.

79 Ssenyonjo M, 'The International Criminal Court and the warrant of arrest for Sudan's President Al-Bashir: A crucial step towards challenging impunity or a political decision' 78 Nordic Journal of International Law, 2009.

Mills K, "Bashir is dividing us': Africa and the International Criminal Court" 34(2) Human Rights Quarterly, 2012. 
of non-cooperation with the ICC, especially over the matter of implementation of the arrest warrant that was issued against Bashir. ${ }^{80}$ Ultimately, therefore, it was foreseeable that the AU would side with Kenyatta in condemning the ICC for pursuing him, given this history that originated the view that Africa was the ICC's sole target in its 'biased' operations.

The Libyan referrals took place within the heat of the civil war in which a no-fly zone had been imposed over the country, thereby lending critical support to the anti-Gaddafi forces as they fought from Benghazi towards Tripoli. ${ }^{81}$ Upset by the manner in which it had again been side-lined on the intervention in Libya, the AU refused to cooperate with the ICC in effecting the warrant of arrest issued against Gaddafi, viewing it as part of an arsenal of weapons deployed to secure regime change. ${ }^{82}$ In hindsight, these reactions of the AU were rather timid in comparison to what was to come later. Following the Bashir referral, the AU pursued a fairly consistent three-pronged line of attack against the ICC and the whole regime of International Justice under the framework of a call for 'African solutions to African problems'. The strategy consisted of: (i) Pursuing the exemption of sitting heads of state from prosecution, which included proposing amendments to the Rome Statute and seeking a referral of the Bashir and Kenyatta cases from the Security Council, both of which were rebuffed; (ii) expressions of broad concern about the application of the principle of universal jurisdiction, ${ }^{83}$ and (iii) calling for the en masse withdrawal of African states parties from the Rome Statute. ${ }^{84}$

The AU did not eventually adopt an official resolution to effect a mass withdrawal of all African states, perhaps on account of the 'positive' outcome of the Kenyatta referral which took the heat off the matter. However, in early 2014, the organisation wrote an extensive critique of ICC procedures, claiming that they undermined the rights of defendants and asserting that they offended basic principles of International Justice..$^{85}$ Of course, an en masse withdrawal from the Treaty

80 See Decision on the Meeting of African States Parties to the Rome Statute of the International Criminal Court, Doc. Assembly/AU/13(XIII), 3 July 2009, para 10.

81 Woolaver H, "Pro-democratic intervention in Africa and the "Arab Spring"' 22 (2) African Journal of International and Comparative Law, 2014, 172-180.

82 Udombana N, 'The ICC on trial: A decade of international criminalisation of Africa' 1(1) Zanzibar Yearbook of Law, 2011, 94-96.

83 Murungu CB, 'Towards a Criminal Chamber in the African Court of Justice and Human Rights' 9(5) Journal of International Criminal Justice, 2011, 1069-1072.

84 See the Resolution of the Extraordinary Session of the Assembly of the AU, Ext/Assembly/AU/ Dec.1 (12 October 2013).

85 Mbaku J, 'Africa's Case against the ICC' Brookings Institution, 13 March 2014 -<http://www. 
was not supported by all African states, but it had a number of vocal and prominent supporters. Such withdrawal would not have affected ongoing prosecutions, but it would nevertheless have been a serious blow to the ICC and to International Law in general. However, the AU took steps which in the long run could be even more damaging than a withdrawal. Thus, amendments were passed to the Protocol on Amendments to the Protocol on the Statute of the African Court of Justice and Human Rights in order to cover criminal matters. ${ }^{86}$ On the face of it this was not a big problem, because it appeared to reflect a serious commitment to address such issues from the regional perspective, and thereby augmenting the international. It could also be said to be giving effect to the doctrine of complementarity, although one could question whether it is regional and not national institutions that should be buttressed in this fashion. The growth of regional institutions around the world has demonstrated the great benefit that can accrue from having a relatively close, familiar and jurisprudentially-related body adjudicating disputes as opposed to one that is both geographically and conceptually distant.

But there are also significant challenges in regionalising the focus of criminal justice. The sting in the tail of the AU amendments to the Protocol is the exemption of sitting heads of state from its purview. ${ }^{87}$ In effect, the AU sought to implement a negative form of complimentarity which detracted from the strength of both the Regional Court (and the ICC of course) and national or domestic courts. Neither could effectively hold the usual perpetrators of gross violations-the state actors-accountable under the law. From an International Law perspective, the exemption also raised a conflict of norms issue as the immediate question of whether or not the amendments contradicted the provisions of the ICC Statute requiring African states parties-who are also members of the AU and therefore bound as well by its constitutive legal documents- to cooperate fully with the ICC. ${ }^{88}$ If it can be established that the amendments are legal and

brookings.edu/blogs/africa-in-focus/posts/2014/03/13-international-criminal-court-mbaku> on 18 March 2020.

86 Otieno HM, 'The merged African Court of Justice and Human Rights (ACJ\&HR) as a better criminal justice system than the ICC: Are we finding African solutions to African problems or creating African problems without solutions?' Academia, 2014.

${ }^{87}$ Article 46A bis, Draft Protocol on Amendments to the Protocol on the Statute of the African Court of Justice and Human Rights ('the Protocol on Amendments') provides: 'No charges shall be commenced or continued before the Court against any serving African Union Head of State or Government, or anybody acting or entitled to act in such capacity, or other senior state officials based on their functions, during their tenure of office' - $<$ http://www.iccnow.org/documents/African_Court_Protocol_-_ July_2014.pdf> on 18 March 2020.

${ }_{88}$ Murungu CB, 'Towards a criminal chamber in the African Court of Justice and Human Rights', at 1087. 
binding' upon the AU states, as the past non-cooperation decision of the AU in respect of the Bashir warrant has been opined to be, ${ }^{89}$ then the question of how, by law, these states could balance their contradictory obligations to the AU and the ICC at the same time come into play. ${ }^{90}$ This matter however presents another broad, legal-scholarly excursion. Nevertheless, the amendments also implicated the principle of pacta sunct servanda - the obligation of good faith cooperation on the part of states-parties to any international treaty. ${ }^{91}$ Additionally, the legal question of concern was whether amendments could be made to a Protocol, which had not yet come into force.

\section{ICC and the Security Council}

The latter two ICC responses raise a second retort. The first is the overtly political context within which the Security Council operates dominated as it is by the political, economic and legal (veto) power of the Permanent Five (P5). Of the five permanent members of the Council two of them-China and the United States — voted against the adoption of the Rome Statute. Furthermore, both countries plus Russia have not ratified the Treaty. To compound matters, once the Treaty came into force the initial actions of the United States did nothing to give succor to the Court. While the Bill Clinton Government was lukewarm to the institution, when George Bush came to power his first action was to withdraw the US signature from the Rome Statute. Although legally ineffectual, the message was clear. More serious measures followed with the passing of the American Service-members Protection Act of 2002. Dubbed the 'Hague Invasion Act', the law provided immunity from prosecution of American soldiers outside US jurisdiction when they committed crimes during war. ${ }^{92}$ The Bush Government then threatened to veto the renewal of all UN peace-keeping missions unless US troops were granted immunity from prosecution by the ICC..$^{93}$ The blackmail re-

89 By virtue of Article 23 of the AU's Constitutive Act. See also Du Plessis M and Gevers C, 'Balancing competing obligations - The Rome Statute and AU obligations' Institute for Security Studies, Paper 225, October 2011, -<https://issafrica.s3.amazonaws.com/site/uploads/Paper225.pdf > on 18 March 2020.

90 Du Plessis M and Gevers C, 'Balancing competing obligations - The Rome Statute and AU obligations'.

91 Du Plessis $\mathrm{M}$ and Gevers C, 'Balancing competing obligations'.

92 Human Rights Watch, 'US: 'Hague Invasion Act' becomes law' Human Rights Watch, 4 August 2002, - <http://www.hrw.org/news/2002/08/03/us-hague-invasion-act-becomes-law $>$ on 18 March 2020.

93 Human Rights Watch, 'US: 'Hague Invasion Act' becomes law' Human Rights Watch, 4 August 2002, - <http://www.hrw.org/news/2002/08/03/us-hague-invasion-act-becomes-law> on 18 March 2020. 
sulted in Security Council Resolution 1422 of 12 July 2002 that granted immunity to personnel from non-states parties to the ICC involved in UN missions. That exemption was only terminated with the embarrassment over the Abu Ghraib scandal concerning US troops abusing Iraqi prisoners. To compound matters, the US embarked on the signing of bilateral immunity agreements (so-called 'BIAs', or 'Article 98 Agreements'), which barred those countries that signed them from surrendering a broad range of US officials, employees and nationals to the ICC.

Secondly, despite whatever technocratic arguments that may be made about the legal autonomy of the Prosecutor and of the independence of the ICC judges, it is quite clear that as important as the decision over individual cases is the situations which arrive in the Court in the first instance and the manner in which they get there. While the Prosecutor may not have much control over situations that are referred by the Security Council, they have a special burden to use their proprio motu powers taking these factors into consideration. The Kenyan cases demonstrated that the Prosecutor should be able to provide effective security for witnesses and to design a framework to ensure that a case holds together from beginning to end. Political pressure should not be the bane of technical incompetence. The Security Council involvement in the ICC via both the mechanism of the referral of cases as well as through the power to defer action on a case smirks of a kind of 'selective justice' at best, or "victor's" justice (Siegerjustiv) at worst. Although the ICC is often at pains to mark distance from the examples of Nuremberg and Tokyo with which it is often associated, it has found it difficult to run away from the charge. As William Schabas pointed out, political choices with regard to criminal prosecutions in the international arena are unavoidable; the key question is between the several choices that can be made, which one is taken? ${ }^{94}$

So far, the Security Council has made choices which seem to emphasise overt political bias rather than to minimise it. Mahmood Mamdani described the charges brought against Bashir as 'demonization masquerading as justice'. According to Mamdani, while there could be no doubt of the need for accountability of those responsible for the violence in Darfur, 'when and how is a political decision that cannot belong to the ICC Prosecutor'. We may add that neither should it be a decision made by the Security Council. Indeed, he goes on to argue that, '[m]ore than the innocence or guilt of the President of Sudan, it is the

94 Schabas W, 'Victor's justice: Selecting 'situations' at the International Criminal Court' 43(3) John Marshall Law Review, 2010. 
relationship between law and politics - including the politicisation of the ICCthat poses a wider issue, one of greatest concern to African governments and peoples'. ${ }^{95}$ Thus, it is unlikely that the Security Council would make a referral of any close ally of the permanent members, which explains the impasse over Syria. Moreover, the African presence on the Security Council in terms of making any serious impact on the process of decision-making is really only cosmetic.

Aside from the selective and inconsistent moves to implement the doctrine on the Responsibility to Protect (R2P), there is also the parallel militarisation of diplomatic relations encapsulated in the war on terror, and the reconstitution of global economic and political power represented most graphically by the emergence of China as a global power with considerable influence in Africa. All of these factors challenge International Law as we know it and are implicated in the discussion of Africa's relations with the ICC.

The political dimensions of this debate are of special interest. Unlike a domestic court that is ostensibly above politics and is buttressed from direct accusations of doing politics by doctrines such as the separation of powers and the independence of the judiciary, these principles do not apply in the case of the ICC. A number of factors distinguish the ICC from both traditional national courts, as well as from its predecessors in the international arena, including the International Court of Justice (ICJ) that deals with disputes between states. The first is that ICC interventions in many instances accompany efforts being made by countries towards securing peace and may reflect an inordinate emphasis on the pursuit of justice. In all the earlier tribunals, the conflict was more or less over; there was little debate between justice and peace. But, it is not simply the pursuit of justice which is at stake but the kind of justice that is being pursued. By its very nature, ICC justice is punitive and retributive and directly undermines the efforts at both reconciling the parties and securing a lasting and sustainable peace. The Bashir referral for example, represented a major step in challenging impunity in Darfur, but it also caused more immediate problems with the humanitarian effort that was underway. This demonstrates that because ICC interventions to date have occurred in deeply contested political waters, it is inevitable that the Court will tend to be instrumentalised to unaccountable political power.

The court is also inclined to depoliticise and silence political debate, projecting its interventions as the neutral and technical action of an international

95 Mamdani M, Saviours and survivors: Darfur, politics and the war on terror, Council for the Development of Social Science Research in Africa (CODESRIA), Dakar, 2010, 325. 
bureaucracy. In this respect, the ICC more closely resembles the International Monetary Fund (IMF) in its interventions on financial austerity and economic reform with similar implications on the sovereignty and autonomous action of the targeted country. But to hide from politics is a difficult endeavour. Despite the similarities, there is a significant distinction between the ICC and institutions like the IMF. The IMF wields both carrot (financial resources) and stick (austerity measures), with the former being used to soften somewhat the blow of the latter. Even the IMF's carrots have not prevented critiques about the lack of accountability and transparency in the institution. On its part, the ICC has no carrot; it is a blunt instrument, which does not generally allow for compromise, with the possible exception of the element of respect for the doctrine of complementarity.

A number of lessons can be gleaned from the Kenyatta referral and abortive trial for the broader discussion about the links between law, politics and international prosecutions in the 21 st century. The first is that much as the political aspects of the case were denied or minimised, they were the very large elephant in the (ICC) courtroom. An international criminal prosecution, especially of a person as high-profile and entrenched as an elected president such as Kenyatta is a very different kettle of fish from one who has been removed from office such as a Slobodan Milosevic or a Charles Taylor. Indeed, the same is even true of Bashir, who although vilified in the West and lacking democratic legitimacy at home, could still find enough support to challenge the rules of the game. Even for deposed presidents like Milosevic and Taylor, the fact that the conduct of their trials did not take place where the crimes were actually committed demonstrated how politically fraught the whole enterprise of international criminal prosecution is. In sum, the legal cannot be divorced from the political.

International Criminal Law-because it is ultimately directed at individual national actors-implicates different notions of law and ideas about its operation. International justice evinces a predominance of western-generated theories and an absence of non-western discourse. Since most international lawyers are westerners or western-trained transnational elites, structural imbalances seep their way into the institutional operation of the ICC. ${ }^{96}$ This explains why even though the case of Uganda prominently brought to the fore traditional methods of criminal justice, they really did not find much traction with the ICC. ${ }^{97}$ In the end, the ICC is left in a deep quandary whereby it is precluded from boldly pursuing any other legitimate cases on the continent by the strong 'anti-Africa'

\footnotetext{
96 Drumbl M, Atrocity, punishment and international law, Cambridge University Press, New York, 2007.

97 Clarke K, Fictions of justice, 95-96.
} 
charge. It has to succumb to a cautious approach in its prosecutory program. While to pronounce the ICC prematurely dead as some of the commentary has tended to do is incorrect, there is no doubt that its experiences with both Kenya and Uganda have left the organisation greatly injured. Whether it will recover and be able to meet the grand vision of ending impunity for human rights violations remains to be seen.

\section{Conclusion}

The African backlash to International Criminal Justice in general and to the ICC in particular lies in a combination of structural, historical and operational factors, and is graphic demonstration of both the strengths and the inherent weaknesses of International Law today. The reaction to the ICC demonstrates that really for the first time, an international regime of law-traditionally dismissed as lacking in teeth-has actually been able to enforce compliance beyond rhetorical flourishes and empty promises. Despite Kenyatta's squirming and Museveni's abuse of the institution, ironically, the actions of both leaders demonstrate how effective the ICC has actually been. But it would be naïve not to acknowledge the weaknesses thrown up by this regime. The first is with respect to the question of sovereign (in)equality. Provided that there are political and economic imbalances in terms of the relations between states, so too will the legal regimes that are designed by the international community be held hostage to them. Obviously, the response of African states is political. However, it is also a response partly influenced by an over-politicisation of the ICC. It makes little difference that the stage on which the politics is being played out is an international one; indeed, that may enhance the problems involved. As Okafor and Ngwaba pointed out, transitional justice mechanisms deployed within the international system are "hardly free from the marked influence of international politics, particularly the successful manipulation of the "semantics of justice", especially by global powers, to suit whatever agenda the relevant actors have in mind at the time'. ${ }^{98}$ It is not enough to focus on the purely technical and juridical dimensions of international institutions without a critical examination of context—economic, social and political..$^{99}$ As Linton and Kiba argued, we need to be

\footnotetext{
98 Okafor OC and Uchechukwu N, 'The International Criminal Court as a 'transitional justice' mechanism in Africa: Some Critical Reflections'9(1) International Journal of Transitional Justice, 2015, 95.

99 Kagoro B, 'The Paradox of Alien Knowledge, Narrative and Praxis: Transitional Justice and the Politics of Agenda Setting in Africa' in Moses C, Chris D, Undine W, Nokukhanya M, Levis O \& Ste-
} 
acutely aware of the larger picture, rather than remain trapped in 'an unhelpful obsession with narrow and artificial discussions about truth versus justice, courts of law versus truth commissions, etc'. According to them, such an approach, focuses on transition and transience, as opposed to stressing normality and regularization of institutions and the functioning of a society. There continues to be a lack of focus on the rule of law. The focus on justice for a moment in time, a transition from one condition to another, is difficult to sustain. ${ }^{100}$

What the two cases explored in this article demonstrate is that while legal issues are important, the more crucial questions are certainly political. This is not simply with respect to the survival and continued effective operation of the ICC. It is also with regard to the question to which the institution was supposedly established to combat: criminal transgressions at the highest level and the reduction and eventual elimination of official impunity.

phen $\mathrm{O}$ (eds), Where law meets reality: Forging African transitional justice, Pambazuka Press, Cape Town/ Dakar/Nairobi/Oxford, 2012, 8-9.

100 Linton S \& Firew T, 'Judges and the rule of law in times of political change or transition' in Cherif Bassiouini M, Gomula J, Mengozzi P, Merrills JG, Navia R, Oriolo A, Schabas W and Vigorito A (eds), The Global Community Yearbook of International Law And Jurisprudence: Global trends: Law, policy and justice (Essays in Honour of Professor Giuliana Ziccardi Capaldo), Oxford University Press, Oxford, 2013, 175. 
